\title{
The kairomonal esters attractive to the Varroa jacobsoni mite in the queen brood
}

\author{
J Trouiller ${ }^{1 *}$, G Arnold ${ }^{1}$, B Chappe ${ }^{2}$, Y Le Conte ${ }^{3}$, \\ A Billion 2, C Masson ${ }^{1}$ \\ ${ }^{1}$ INRA-CNRS, Laboratoire de Neurobiologie Comparée des Invertébrés, \\ BP 23, 91440 Bures-sur-Yvette; \\ 2 CNRS, Institut de Chimie des Substances Naturelles, 91198 Gif-sur-Yvette; \\ 3 INRA, Station de Recherches de Zoologie et d'Apidologie, 84143 Montfavet Cedex, France
}

(Received 29 March 1993; accepted 24 September 1993)

\begin{abstract}
Summary - In the queen brood, methyl and ethyl esters reach their maximum secretion around the capping period. During this period, 3 kairomonal esters attractive to the parasitic mite Varroa jacobsoni are secreted by queen brood at half the rate found for worker brood. Methyl oleate, repellent to the mite, is secreted in large amounts compared with the attractive esters. Quantitative and qualitative differences in the esters present on worker, drone, and queen broods could partially explain the weaker attraction exerted by queen brood on the mite, compared with the attractive effects of worker and drone broods.
\end{abstract}

brood pheromone / ethyl ester / methyl ester / kairomone / queen brood / Varroa jacobsoni

\section{INTRODUCTION}

The paratistic mite Varroa jacobsoni Oud is now the most important worldwide threat to honey bees (Apis mellifera L) (Ritter, 1981; Arnold, 1990). To reproduce, the female mite enters a cell containing a honey bee larva. After the cell has been capped by adult workers, the mite begins to lay eggs, and its offspring grows at the expense of the bee pupa. When the adult bee emerges from its cell, only the fully developed adult mites survive, whereas the males and immature females die (Grobov, 1977).

The reproductive rate of the mite depends partly on the sex and caste of the host brood. Fertility is higher on drone brood than on worker brood. Approximately $95 \%$ and $73 \%$ of infesting female mites lay eggs on drone and worker broods, respectively (Schulz, 1984), but only about $10 \%$ lay eggs on the queen brood (Harizanis, 1991). The number of adult mite offspring depends on the amount of time the cell is capped. The

* Present address: Simon Fraser University, Department of Chemistry, Burnaby, BC V5A 1S6, Canada. 
capped brood period is $14-15 \mathrm{~d}$ in drone brood, 11-12 $\mathrm{d}$ in worker brood, and $8 \mathrm{~d}$ in queen brood. The minimum development time for adult male and female mites is at least $10 \mathrm{~d}$ after cell capping (Rehm and Ritter, 1989). Consequently, no offspring can develop on queen brood, whereas 4-5 and 2-3 females can theoretically develop on drone and worker broods respectively. According to these observations, the mite population undergoes significant selection favouring the avoidance of queen brood, and a preference for drone over worker broods.

This hierarchy in host choice is actually demonstrated by the mites in infested colonies. The infestation rate is ca 5-9 times higher in drone than in worker broods (Sulimanovic et al, 1982; Issa et al, 1986; Schulz, 1984). Queen brood is only infested when the population of mites is high; under these conditions, the presence of open worker brood greatly lessens the infestation rate of queen brood (Harizaris, 1991). It seems than the parasite can differentiate among the brood according to its sex and caste, and that queen brood is less attractive to the mite.

Four of the 10 methyl and ethyl fatty acid esters secreted by the bee larvae have a strong effect on the capping behaviour of adult worker bees (capping esters (CE): methyl palmitate (MP); methyl oleate (MO); methyl linoleate $(\mathrm{ML})$; and methyl linolenate $(M L N)$ ), whereas the effects of the 6 other esters are weak or non-existent (Le Conte et al, 1990). The intensive secretion of these esters by worker larvae shortly before metamorphosis elicits the capping behaviour of adult bees (Trouiller et al, 1991).

Two of the pheromonal compounds, MP and $M L N$, and a quite inactive ester, ethyl palmitate (EP), are also attractive to female mites (Le Conte et al, 1989). These kairomonal/pheromonal compounds are secreted by worker and drone broods a few hours before the cell is capped (Trouiller et al, 1991, 1992), which coincides with the period when mites infest the bee brood
(Boot et al, 1991; Wieting and Ferenz, 1991). Mites use a part of the bee brood pheromonal signal to locate and infest hosts.

During the period before the capping, the kairomonal compounds are 5-6 times more abundant in drone brood than in worker brood, and an abundant secretion is present over a longer period of time. These differences could explain the preference for drone brood by the mite. These compounds seem to allow the bee to locate an adequate host, and to choose the sex and caste of the brood it will infest.

In this work, we investigate the presence of the esters in queen brood, and the possible correlation between the quantitative and qualitative aspects of the queen brood ester secretion and the infestation rates by the Varroa mite according to the sex and caste of the bee larvae.

\section{MATERIALS AND METHODS}

\section{Queen brood}

Honeybee (Apis mellifera) sister larvae (4 d old from egg laying) were grafted into artificial queen cells. Thirty grafted cells were placed in a queenless colony and the larvae were reared by the workers. The operation was repeated 12 times in different colonies. The larvae were removed at different stages of their development:

-2 samples of 50 individuals at the 7 th day of the development (about $1 \mathrm{~d}$ before capping (BCA)).

-3 samples of 50 individuals at the 8 th day of the development (not yet spinning larvae in capped cells (CAP)).

-2 samples of 50 individuals at the 11 th day of the development (white-eyed pupae (PUP)).

\section{Chemical analysis}

Each sample was extracted successively with pentane and dichloromethane. The 2 extracts 
were mixed and then fractionated on a open silicagel chromatographic column. The semipolar fraction, obtained by fractionating with dichloromethane, was then purified using HPLC with a silica column (mobile phase: heptane/ethyl acetate, 95:5). The presence of the 10 esters identified in the worker and drone broods was confirmed with GC-MS analysis; the esters were quantified by GC. The detailed protocol has been described previously (Trouiller et al, 1992).

\section{RESULTS AND DISCUSSION}

The 10 methyl and ethyl esters (total esters) identified in worker and drone broods were also present in queen brood (table I). In the 2 samples of uncapped queen larvae (BCA), the amounts of total esters were heterogeneous. As the mean weight of the larvae differs according to the samples, growth rate variations could be involved in the differing amounts of esters. At the end of capping (CAP), total esters reached their maximum value, and then decreased. In white-eyed pupae (PUP), the total esters were about 3 times less than around the capping period. As in worker and drone broods, the maximum secretion of esters was reached around the capping period. However, in white-eyed queen pupae, esters were relatively abundant compared with levels found in drone and worker pupae.

The amount of total esters at the end of the capping in queen brood (ca $520 \mathrm{ng} / \mathrm{indi}$ vidual) was close to the worker brood value (ca $560 \mathrm{ng} /$ individual), but was less than in drone brood (ca $1850 \mathrm{ng} /$ individual) (Trouiller et al, 1991, 1992). However, since

Table I. Amounts of esters (ng/individual) in queen brood of different development stages.

Ester

Amount of ester (ng/individual) in queen brood at development stage

$\frac{B C A}{161^{a} 122^{a}} \frac{C A P}{232^{a} 207^{a} 261^{a}} \frac{P U P}{282^{a} 269^{a}}$

\begin{tabular}{|c|c|c|c|c|c|c|c|}
\hline Methyl palmitate (MP) (mg/individual) & 15 & 3 & 23 & 16 & 26 & 5 & 20 \\
\hline Methyl stearate (MS) (mg/individual) & 7 & 4 & 17 & 7 & 20 & 9 & 7 \\
\hline Methyl oleate (EMO) (mg/individual) & 101 & 44 & 189 & 191 & 215 & 56 & 82 \\
\hline Methyl linoleate (ML) (mg/individual) & 3 & 1 & 7 & 5 & 8 & 5 & 3 \\
\hline Methyl linolenate (MLN) (mg/individual) & 49 & 18 & 31 & 56 & 35 & 2 & 8 \\
\hline Ethyl palmitate (EP) (mg/individual) & 11 & 4 & 25 & 15 & 29 & 3 & 10 \\
\hline Ethyl stearate (ES) (mg/individual) & 3 & 3 & 20 & 9 & 23 & 10 & 3 \\
\hline Ethyl oleate (EO) (mg/individual) & 49 & 25 & 150 & 126 & 171 & 38 & 40 \\
\hline Ethyl linoleate (EL) (mg/individual) & 0 & 1 & 3 & 3 & 4 & 1 & 1 \\
\hline Ethyl linolenate (ELN) (mg/individual) & 57 & 16 & 38 & 50 & 44 & 7 & 12 \\
\hline Varroa esters (VE) ${ }^{\circ}$ (mg/individual) & 75 & 25 & 79 & 87 & 90 & 10 & 38 \\
\hline Total esters (TE) ${ }^{\circ}(\mathrm{mg} /$ individual) & 295 & 119 & 503 & 478 & 575 & 136 & 186 \\
\hline Mean VE b (mg/individual) & \multicolumn{2}{|c|}{50} & \multicolumn{3}{|c|}{85} & \multicolumn{2}{|c|}{24} \\
\hline Mean TE c (mg/individual) & \multicolumn{2}{|c|}{207} & \multicolumn{3}{|c|}{519} & \multicolumn{2}{|c|}{161} \\
\hline
\end{tabular}

BCA: larvae before their cells are capped; CAP: not yet spinning larvae in capped cells; PUP: white-eyed pupae; a weights are mean values (mg/individual); b VE: Varroa esters, the 3 kairomonal compounds $(M P+E P+M L N)$; cTE: total esters, the amounts of the 10 methyl and ethyl esters. 

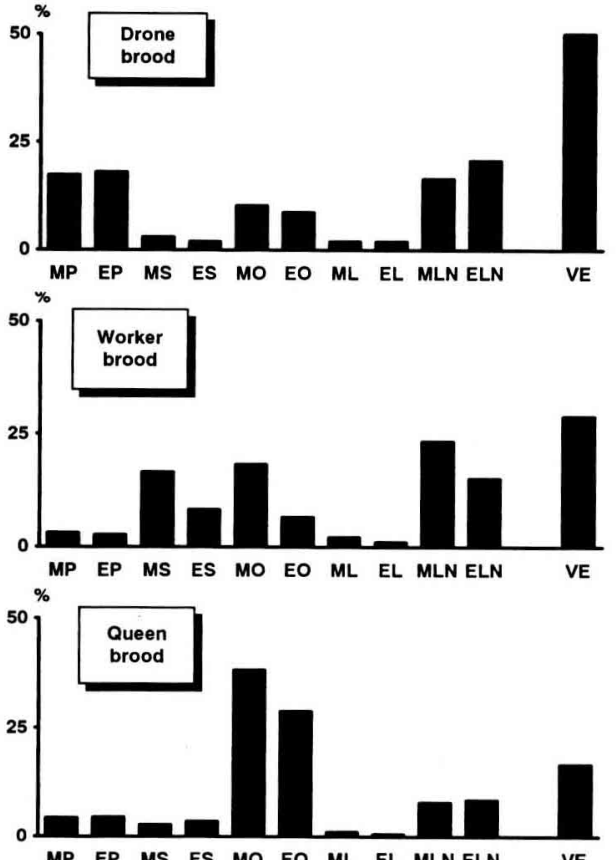

MP EP MS ES MO EO ML EL MLN ELN VE

Fig 1. Proportion of esters in regard to total esters $(\%)$ in honey-bee brood at the end of the capping period. Abbreviations of esters can be found in table 1 . the queen and drone broods were not studied during the same period, a seasonal change of the amounts of esters was still possible. In the 3 types of brood, the esters were secreted in different proportions according to the sex and the caste of the larvae (fig 1). The esters proportions changed during growth in drone and worker broods, but did not change within the 3 development stages of the queen brood studied.

At the end of the capping period, the 3 attractive esters were 3 times less abundant in queen larvae (VE $85 \mathrm{ng} /$ individual) than in worker brood (VE $170 \mathrm{ng} /$ individual), and much less abundant than the levels found in drone brood (VE $950 \mathrm{ng} /$ individual) (Trouiller et al, 1991, 1992). Two factors could explain the weaker attraction elicited by queen larvae to Varroa (fig 2). First, the amounts of the 3 kairomonal esters were low; the most abundant of the 3 was the least attractive (MLN) (Le Conte et al, 1989). Second, the amounts of methyl oleate (MO) were high compared with the levels of the 3 attractive esters. MO is repellent to the mite (Le Conte, 1990) and could therefore limit the attraction of the chemical signal emit-

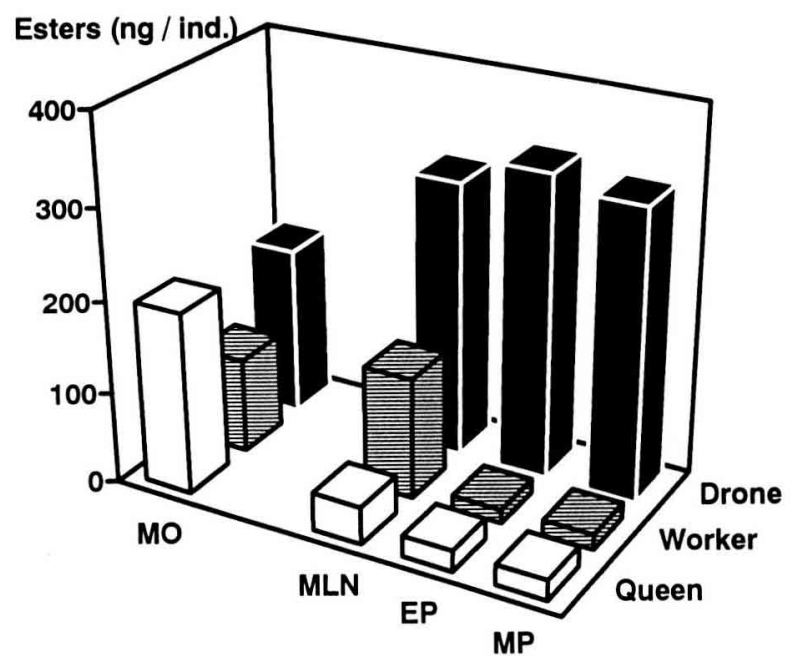

Fig 2. Amounts of kairomonal esters at the end of the capping period in drone, worker, and queen broods. The attractive esters in increasing effect order are: MLN, EP, and MP. MO is repellent to the mite. 
ted by queen larvae. However, other unidentified repellent compounds could have an important role in the weak attraction elicited by queen larvae. Several pheromonal compounds secreted by adult bees are repellent towards Varroa jacobsoni (Hoppe and Ritter, 1988; Kraus, 1990). Since their amounts increase with the bees age, they could be responsible for the weaker attraction of foragers compared to nurse bees (Kraus et al, 1986).

Other non-larval factors could also play an important role in the Varroa queen brood interactions. Royal jelly appears to be repellent towards the mite (Le Conte, 1990). Thus, the presence of large amounts of royal jelly in the cells could partly explain the weak attraction elicited by queen brood. The prominence of queen cells could also limit the accessibility of the mite to the larval esters.

Recently, Rickli et al (1992) showed that palmitic acid was at least as attractive to Varroa as methyl palmitate. Palmitic acid is more abundant on the larvae than the 3 esters. Thus, palmitic acid may play a major role in eliciting mites to infest brood. However, this compound is also present on adult bees, on pollen, and on different aged larvae (Tulloch, 1971; Blomquist et al, 1980), although esters are present in very small amounts in pollen and in adult bees (Trouiller, unpublished data). Accordingly, palmitic acid does not seem to be a semiochemical specific to brood. It would be interesting to quantify the amounts of palmitic acid in brood of different ages, sex, and caste. Palmitic acid and the esters could play successive roles in mite invasion since the acid is a generalistic bee signal, and the esters are more specific to the final larval stage (L5). The relative importance of semiochemicals, and particularly of esters in the infestation of worker and queen brood has yet to be demonstrated. Contact chemicals could have a major role in the infestation process. Other parameters, like tempera- ture (Le Conte and Arnold, 1988) and the distance between the larva and the cell top (Goetz and Koeniger, 1992), have also been proposed as possible cues for the mite. However, the latter study did not exclude a possible chemical aspect linked to the physical features. At present, it can be said that the qualitative and quantitative aspects of the esters secreted by bee brood of different age, sex, and caste fit the laboratory and colony behavioural observations well, and that this volatile signal could at least partly explain the difference of infestation among bee brood.

The maximum secretion of the esters occurs around the capping period in queen brood, as in worker and drone broods (Trouiller et al, 1991, 1992). However, a pheromonal role of the esters was not demonstrated in the capping behaviour of drone or queen cells. Other possible pheromonal roles of the esters have yet to be demonstrated, allthough these compounds seem to be involved in inhibition of ovary development and stimulation of hypopharyngeal gland growth (Le Conte et al, 1991; Arnold et al, 1994).

\section{ACKNOWLEDGMENT}

We thank J Pettis (Department of Biology, Simon Fraser University, Burnaby, BC Canada) for his assistance in the English translation.

\section{Résumé - Dosage des esters kairomo-} naux attractifs pour l'acarien Varroa jacobsonidans le couvain de reine. Pour se reproduire, l'acarien parasite de l'abeille, Varroa jacobsoni, pénètre dans une cellule contenant une larve d'abeille. En colonie, l'acarien montre une nette préférence pour le couvain de mâle par rapport à celui d'ouvrière (Sulimanovic et al, 1982 ; Issa et al, 1986 ; Schulz, 1984), et il n'infeste le couvain de reine que lorsqu'une colonie est très 
infestée (Harizaris, 1991). Trois esters d'acides gras sécrétés par le couvain d'abeille sont des composés kairomonaux attractifs vis-à-vis de l'acarien ; ce sont, par ordre décroissant d'attractivité, le palmitate de méthyle (MP), le palmitate d'éthyle (EP) et le linolénate de méthyle (MLN). Parmi les 6 autres esters méthyliques et éthyliques qui ont été identifiés sur la cuticule du couvain d'abeille, l'un d'entre eux, l'oléate de méthyle (MO), est répulsif pour l'acarien, les autres n'ayant pas d'activité (Le Conte et al, 1989 ; Le Conte, 1990). Dans les couvains de mâle et d'ouvrière, la sécrétion des 3 esters kairomonaux, très faible chez les jeunes larves, s'intensifie peu avant l'operculation de la cellule (Trouiller et al, 1991, 1992), à l'âge où le couvain est infesté par l'acarien (Boot et al, 1991; Wieting et Ferenz, 1991). Ces esters sont en quantité plus importante dans le couvain de mâle que dans le couvain d'ouvrière (Trouiller et al, 1992). Au cours de ce travail, nous avons quantifié les 10 esters dans le couvain de reine, à différents stades de son développement, dans le but de vérifier s'il existe une cohérence entre les paramètres qualitatif et quantitatif de la sécrétion du couvain de reine, et les données comportementales rapportées dans la littérature. Deux lots de larves de reine prélevées environ $1 \mathrm{j}$ avant l'operculation de leur cellule (BCA), 3 lots de larves de reine non filantes et dont les cellules étaient operculées (CAP), et 2 lots de pupes non pigmentées (PUP) ont été extraits et analysés. Nous avons montré que les 10 esters identifiés dans le couvain de mâle et d'ouvrière sont aussi présents dans le couvain de reine, et que la sécrétion maximum apparaît aussi au moment de I'operculation (tableau I). À la fin de l'operculation, les proportions des esters sont différentes selon le sexe et la caste du couvain (fig 1). La quantité d'esters kairomonaux (MP, EP et MLN) est 3 fois plus faible dans le couvain de reine par rapport au couvain d'ouvrière et 11 fois moindre par rapport à celui de mâle (fig 2). MLN, l'ester le moins attractif pour l'acarien, constitue chez la reine la majeure partie des esters kairomonaux. L'ester répulsif pour l'acarien (MO) est, relativement aux esters attractifs, en quantité importante dans le couvain de reine (fig 2). Ceci pourrait, au moins en partie, expliquer la faible attraction exercée par le couvain de reine sur l'acarien. Quel que soit le type de couvain (sexe, caste et âge), les paramètres qualitatif et quantitatif de la sécrétion des esters (Trouiller et al, 1991, 1992) sont cohérents avec les données comportementales décrites dans la littérature (Sulimanovic et al, 1982 ; Issa et al, 1986 ; Schulz, 1984; Boot et al, 1991 ; Harizaris, 1991 ; Wieting et Ferenz, 1991). L'utilisation de ces 4 composés phéromonaux (Le Conte et al, 1990; Le Conte et al, 1991), sécrétés par le couvain d'abeilles, semble être une adaptation bénéfique de l'acarien à la société d'abeille, et lui permet d'infester un hôte optimum pour sa reproduction, et au moment propice, c'est-à-dire peu avant l'operculation de la cellule.

\section{couvain de reine / ester d'acides gras / operculation / kairomone / phéromone de couvain / Varroa jacobsoni}

\section{Zusammenfassung - Die für Varroa jacobsoniattraktiven kairomonalen Ester} in der Königinnenbrut. Das Weibchen von Varroa jacobsoni, einer parasitischen Milbe der Honigbiene, dringt zur Fortpflanzung in eine Brutzelle ein. Im Bienenvolk zeigt diese Milbe eine deutliche Bevorzugung von Zellen mit männlichen gegenüber solchen mit weiblichen Larven (Sulimanovic et al, 1982; Schulz, 1984; Issa et al, 1986) und sie befällt Königinnenbrut nur dann, wenn das Volk einen sehr hohen Infestationsgrad aufweist (Harizaris, 1991). Drei Fettsäureester, die von der Bienenbrut abgeschieden werden, wirken auf die Milbe als attraktive Kairomone; es sind dies, in absteigender Reihenfolge ihrer Attraktivität: Methylpalmitat (MP), Äthylpalmitat (EP) und Methyllinolenat 
(MLN). Unter den sechs anderen Methylunf Äthylestern, die auf der Kutikula der Bienenbrut festgestellt wurden, hat sich einer, Methyloleat (MO), gegenüber der Milbe als repellent gezeigt, während die übrigen keinerlei Wirkung ausübten (Le Conte et al, 1989; Le Conte, 1990). Bei der Drohnenund Arbeiterbrut steigt die bei jungen Larven sehr geringe Sekretion der drei KairomonEster vor der Verdeckelung der Zelle an (Trouiller et al, 1991, 1992), also in dem Alter, in dem die Brut von der Milbe befallen wird (Boot et al, 1991; Wieting und Ferenz, 1991). Diese Ester werden bei der Drohnenbrut in größerer Menge gefunden als bei Arbeiterbrut (Trouiller, 1992). Im Laufe der vorliegenden Arbeit haben wir die 10 Ester in der Königinnenbrut in verschiedenen Entwicklungsstadien quantifiziert, um festzustellen, ob ein Zusammenhang zwischen der Sekretion durch die Königinnenbrut und dem in der Literatur berichteten Verhalten besteht. Es wurden zwei Gruppen von Königinnenlarven, die ungefähr einen Tag vor der Verdeckelung standen (BCA), drei Gruppen von Larven aus verdeckelten Zellen, aber noch vor dem Spinnen (CAP), und zwei Gruppen von weißen Puppen (PUP) extrahiert und analysiert. Wir konnten zeigen, daß die 10 Ester, die aus der Arbeiter- und Drohnenbrut bestimmt wurden, auch in der Königinnenbrut vorhanden sind, und daß sie ebenfalls zur Zeit der Verdeckelung ihre größte Menge erreichen (Tabelle I). Bei Abschluß der Verdeckelung sind die Proportionen der Ester sowohl nach dem Geschlecht wie nach der Kaste der Brut verschieden (Abb 1). Die Menge der Kairomon-Ester (MP, EP and $M L N$ ) sind in der Königinnenbrut nur in einem Drittel der Menge vorhanden wie in der Arbeiterbrut und elf mal weniger als in der Drohnenbrut (Abb 2). MLN, der für Milben am wenigsten attraktive Ester, stellt die Hauptmenge der Kairomon-Ester. Dagegen ist der für die Milben als Repellent wirkende Ester (MO) im Vergleich zu den attraktiven Estern in der Königinnenbrut in größerer
Menge vorhanden (Abb 2). Dies könnte, wenigstens teilweise, die geringere Attraktivität der Königinnenbrut für die Milben erklären. Für alle Bruttypen (Geschlecht, Kaste, Alter) stimmen die qualitativen und quantitativen Werte der abgesonderten Ester (Trouiller et al, 1991, 1992) gut mit den in der Literatur beschriebenen Beobachtungen über das Verhalten überein. Die Benützung dieser von der Bienenbrut abgesonderten vier Pheromon-Verbindungen scheint eine günstige Anpassung der Milbe an den Bienenstaat zu sein, die es ihr ermöglicht, einen für seine Fortpflanzung optimalen Wirt zu befallen, und zwar im geeigneten Zeitpunkt, das heißt vor der Verdeckelung der Zelle.

Königinnenbrut / Methyl- und Äthylester von Fettsäuren / Kairomone / Brutpheromone / Varroa jacobsoni/ Verdeckelung

\section{REFERENCES}

Arnold G (1990) Current and recent research on Varroa. Am Bee J 130, 257-261

Arnold G, Le Conte $Y$, Trouiller 3 , Hervet $H$, Chappe B, Masson C (1994) Inhibition of worker ovaries development by a mixture of fatty acid esters from larvae. CR Acad Sci (in press)

Blomquist GJ, Chu AJ, Remaley S (1990) Biosynthesis of wax in the honeybee, Apis mellifera L. Insect Biochem 10, 313-321

Boot WJ, Calis JNM, Beetsma J (1991) Invasion of Varroa mite in honeybee brood cells: observation of Varroa mite behaviour. In: Proc Int Sympt on Recent Research on Bee Pathology (W Ritter, ed), Apimondia, Gent, 43-44

Goetz B, Koeniger N (1992) Structural features trigger brood cell invasion of Varroa Jacobsoni. Apidologie 23, 211-216

Grobov OF (1977) La Varroase des abeilles. In: La varroase-maladie des abeilles. Apimondia, Bukarest, 52-79

Harizanis PC (1991) Infestation of queen cells by the mite Varroa jacobsoni. Apidologie 22, 533-538

Hoppe H, Ritter W (1988) The influence of the Nasonov pheromone on the recognition of house bees and foragers by Varroa jacobsoni. Apidologie 19, 165-172

Issa MRC, de Jong D, Gonçalves LS (1986) Study of the preference of the mite Varroa jacobsoni for Apis 
mellifera drones. In: $X X X$ th Int Apic Congr, Apimondia, Tokyo, $159-160$

Kraus B (1990) Effects of honey-bee alarm pheromone compounds on the behaviour of Varroa jacobsoni. Apidologie 21, 127-134

Kraus B, Koeniger N, Fuchs S (1986) Unterscheidung zwischen Bienen verschiedenen Alters durch Varroa jacobsoni Oud und Bevorzugung von Ammenbienen im Sommerbienenvolk. Apidologie 19, 257-266

Le Conte $Y(1990)$ Contribution à l'étude des relations abeille-Varroa. Thèse Doct Sci, Paris XI, Orsay

Le Conte Y, Arnold G (1988) Étude du thermopréférendum de Varroa jacobsoni Oud. Apidologie 19, 155-164

Le Conte Y, Arnold G, Trouiller J, Masson C, Chappe B, Ourisson $G$ (1989) Attraction of the parasitic mite Varroa to the drone lavae of honey bees by simple aliphatic esters. Science 245, 638-639

Le Conte Y, Arnold G, Trouiller J, Masson C, Chappe B (1990) Identification of a brood pheromone in honeybees. Naturwissenschaften 77, 334-336

Le Conte Y, Amold G, Trouiller J, Masson C, Chappe B, Ourisson $\mathrm{G}$ (1991) In: The behaviour and physiology of bees (Goodman LJ and Fischer RC, eds), CAB International, London, 69-76

Rehm SM, Ritter W (1989) Sequence of the sexes in the offspring of Varroa jacobsoni and the resulting consequences for the calculation of the development period. Apidologie 20, 339-343
Rickli M, Guerin PM, DiehI PA (1992) Palmitic acid released from honeybee worker larvae attracts the parasitic mite Varroa jacobsoni on a servosphere. Naturwissenschaften 79, 320-322

Ritter W (1981) Varroa disease of the honey bee Apis mellifera. Bee World 62, 141-153

Schulz AE (1984) Reproduktion und Populationsentwicklung der parasitschen Milbe Varroa jacobsoni Oud in Abhängigkeit vom Brutzyklus ihres Wirtes Apis mellifera L. Apidologie 15, 401-420

Sulimanovic D, Ruttner F, Pechhacker $H$ (1982) Studies on the biology of reproduction in Varroa jacobsoni. Honeybee Science 3, 109-112 (in Japanese)

Trouiller J, Arnold G, Le Conte Y, Masson C, Chappe B (1991) Temporal pheromonal and kairomonal secretion in the brood of honeybees. Naturwissenchaften $78,368-370$

Trouiller J, Arnold G, Chappe B, Le Conte Y, Masson $C$ (1992) Semiochemical basis of infestation of honey bee brood by Varroa jacobsoni. J Chem Ecol 18, 2041-2053

Tulloch AP (1971) Beewax: structure of the esters and their component hydroxyacids and diols. Chem Phys Lipids 6, 235-265

Wieting J, Ferenz HJ (1991) Behavioral study on the invasion of honey bee brood by the mite Varroa jacobsonion wax combs and ANP combs. Am Bee $J 131,117-118$ 